\title{
'Some Thoughts about Neurological Recovery in Spinal Cord Injuries: A Philosophical Review'
}

\author{
F. W. Meinecke \\ Querschnittgelähmten-Zentrum des Berufsgenossenschaftlichen Unfallkranken- \\ hauses, 2000 Hamburg, FRG
}

\section{Summary}

In 1969 Michaelis published an inquiry on diagnosis and prognosis in traumatic spinal cord lesions based on an international level of experience. Fifteen years later our own answers from 1967 are revised. The result of the first assessment depends on the patient's condition and the physician's experience during the examination in the early stage. A correction of the first diagnosis in due course is not rare. There was no great alteration necessary for comparison in 1983 with the answers given in 1969.

Firm diagnosis and prognosis are urgently needed by patients, relatives, employers and insurance bodies as early as possible. They are required also in order to compare the results of different methods of treatment. In addition, we treated a greater number of incomplete tetraplegics below C5/6, accompanied by a complete irreversible paralysis of the M. deltoideus. The pathology of this syndrome is still unknown.

Key words: Spinal cord injury; Firm diagnosis; Firm prognosis; Unusual tetraplegia.

In 1967 Michaelis carried out his worldwide inquiry on the subject of 'Neurological Terminology and Prognosis in Paraplegia and Tetraplegia'. He summarized the answers and added his own recommendations. My own views at that time were based on the experience of 10 years work in the field of paraplegia in a 33-bedded unit in an Accident-Hospital of the Workmen's Compensation board, situated in the area of coal mines and steel industry, both very busy at that time.

In 1981 we opened the new 100-bedded Spinal Cord Injuries Centre, attached to the Workmen's Compensation Accident Hospital in Hamburg. At that time I got the impression it should be mandatory to revise personal standpoints regarding neurological prognosis. It seemed to me specially urgent as the controversy between conservative and operative treatment of traumatic lesions became more acute. So I would like to raise some questions that I feel are important to every member of the staff concerned and also to the patient himself and his family. 


\section{First Question}

If it is true that incomplete lesions have a better prognosis then complete lesions, how can we confirm this important point during the first assessment in the early stage?

There are two vital points:

1. What is the patient's condition during the first examination? Is he conscious, is he tired, is he under drugs? Is he in shock? Is he suffering from associated injuries probably more severe than the spinal lesion?

2. What of the examining doctor's training? Is he experienced in neurological examination?

The result of the examination depends on the patient's ability to cooperate and the doctor's ability to carry out a meticulous assessment. In my experience the most critical points during this procedure are the proper positioning in order to examine motor function and the patience to perform a thorough examination of sensation, including all modalities.

If there is a complete motor and sensory lesion we believe no recovery of functional value is to be expected. Repeated examinations will end with the same result. If not (if the slightest return of motor function or even sensibility return can be seen), was then the first stage an incomplete examination or an incomplete lesion?

\section{Second question}

If there exists a real incomplete lesion what is the estimated recovery in time and extent? It was Hardy who asked many years ago during a discussion: 'How complete is complete, how incomplete is incomplete?' This wise question has never been answered in a satisfactory way. We all know the many variations of incomplete lesions, e.g. motor complete, sensory incomplete and vice versa, so called subtotal paralysis, sacral sparing, the anterior, posterior and central cord syndrome. In my opinion one can give patients some hope for recovery in all those cases but one should avoid reassuring them that this will happen automatically.

Coming back to Michaelis' paper published in 1969, I reiterated in my publications that if there is no sign of recovery occurring within 48 hours after injury there will be no hope of functional useful recovery in complete lesions. Revising 173 cases in which some recovery was to be seen, none of the few initial (apparently complete), lesions proved definitely to be complete during the period of hospitalization. Mostly there could be found some areas of sensory sparing by repeated assessment within the first few hours and days. So in complete lesions one may wait as Michaelis recommended for 3 weeks for a firm prognosis. On the other hand one may postpone the diagnosis 'complete lesion' as long as an experienced examiner will be certain of this in a patient capable of full co-operation. The physiotherapists may be of great help in this very important examination. It is not merely of academic interest to make a firm diagnosis. This diagnosis not only influences the patient's psychological 
condition but also all the preparations for the patient's future life after his discharge from hospital. This cannot be started too early.

Seeing so many patients at the same time in a new large unit (admitted mainly early after the onset of injury), I got the impression that useful functional recovery could be expected in complete lesions in a higher percentage than has been thought in former years. That impression cannot be confirmed up to now. Therefore, to postpone the firm diagnosis in initial complete paraplegia for three weeks and for six weeks in tetraplegia seems not justified.

In initial incomplete lesions it seems justifiable to postpone the final judgement for 6 months as Michaelis recommended. There may be some exceptions but we did not see more than one or two patients with incomplete tetraplegia where useful functional recovery eccurred later than 26 weeks after the onset of injury. This fact should not be confused with adaptation, training and exercise results. Patients may gain a greater extent of independency by these means but this has nothing to do with regeneration of lost parts of the nervous system.

With that in mind it seems justifiable to give definitive and firm reports to insurance companies after 6 months for paraplegics as well as for tetraplegics, so that they may be able to make their final decisions. Sequelae of neural lesions will not improve after that time. Worsening by post-traumatic syringomyelia later is another issue.

In conclusion, we do feel that very little has changed since Michaelis' publication but we should become more aware of the extent of the initial spinal cord lesion to enable us to give, as early as possible, a firm diagnosis and prognosis to patients, relatives and doctors. This involves not only the preparations for the patient's future life but also the expected results of conservative or operative treatment after the onset of a spinal cord injury.

I would like to mention another problem and one which we have the opportunity to see more frequently. These are patients who have sustained a C5/6 level tetraplegia; thus they are able to move the m. biceps and the m. extensor carpi radialis but the $\mathrm{C} 4$ innervated $\mathrm{m}$. deltoid is (and remains), completely paralysed. While the aforementioned muscles in due course become stronger patients remain quite unable to move the shoulder. In one of them movement of the fingers, grade $1-3$ on the right returned as well as muscle power in the right leg and foot but there was no recovery of the right $\mathrm{m}$. deltoid. On the left $\mathrm{m}$. triceps brachii recovered from $0-3$ and the $\mathrm{m}$. deltoid improved from 1-4. Deep sensation improved bilaterally, right side more than left. The final outcome 8 months after injury was mainly an anterior-cord-syndrome. The bony lesion was a C4/5 fracture-luxation, fused at the day of accident elsewhere.

As mentioned before, we see these patients more frequently year by year. This raises the questions as to the pathology, as below the upper limit of the lesion (C4) there is still voluntary movement with the possibility of improvement of motor power and even neurological restoration of lost functions.

The aim of this presentation is to revise some ideas and experiences we used over the years and to ask questions in order to solve problems hard to understand. We feel we need further investigations on a broad level from many countries. The answers concerning prognosis are of tremendous importance with regard to the patients' psychology, the comparability of various methods of treatment in the early stage and the questions asked by insurance bodies of different kinds. 
Therefore I would like to suggest the setting up of a special working group dealing with this problem.

This later review regarding the discrepancy in the neurological findings should encourage people, in particular neurologists and neuropathologists, to carry out further investigations into what happens to the spinal cord and the nerve roots when injured.

\section{Résumé}

En 1969 Michaelis a publié une enquête sur le diagnostic et le pronostic à l'égard des lésions traumatiques de la moëlle épinière, basée sur un niveau international d'expérience. 15 ans plus tard on en est à la révision de nos propres résponses de 1967. Le résultat de la première évaluation dépend de la condition du malade et de l'expérience du médecin pendant l'examen lors de la première phase. Une rectification du premier diagnostic en temps utile n'est certes pas rare. Aucune grande modification ne s'avouait nécessaire en ce qui concerne la comparaison en 1983 avec les réponses données en 1969.

Un diagnostic et un pronostic fermes sont exigés d'urgence par les malades, le parentage, les patrons et les sociétés d'assurances le plus tôt possible. On en a besoin aussi pour comparer les résultats de diverses méthodes de traitement. En outre, nous avons plus fréquemment traité des malades qui souffraient de la tétraplégie incomplète au-dessous de C5/6, accompagnée d'une paralyse complètement irréversible du $\mathrm{M}$. deltoideus. La pathologie de ce syndrome reste toujours inconnue.

\section{Zusammenfassung}

Michaelis hat 1969 eine auf einem internationalen Erfahrungsniveau basierende Untersuchung der Diagnose und Prognose bei Rückenmarkverletzungen veröffentlicht. 16 Jahre später werden unsere eigenen Antworten von 1967 überprüft. Das Ergebnis des ersten Befundes hängt vom Zustand des Patienten und von der Erfahrung des Arztes während der Untersuchung in der Erfahrung des Arztes während der Untersuchung in der Akutphase ab. Eine Korrektur der ersten Diagnose im Laufe der Zeit ist keinesfalls ungewöhnlich. Eine große Änderung war im Vergleich von 1983 mit den 1967 gegebenen Antworten nicht notwendig.

Eine sichere Diagnose und Prognose sind dringend notwendig und zwar so früh wie möglich für Patienten, Verwandte, Arbeitgeber und Versicherungen. Man braucht sie auch um die Ergebnisse von verschiedenen Behand-lungsmethoden zu vergleichen. Außerdem haben wir häufiger unvollständige Tetraplegien unterhalb $\mathrm{C}_{5: 6}$ behandelt, bei denen eine vollständige Lähmung des M. deltoideus bestand. Die Pathologie dieses syndroms ist roch unbekannt.

\section{Reference}

MICHAELIS LS 1969 International inquiry on neurological terminology and prognosis in paraplegia and tetraplegia. Paraplegia 7:1-5. 